\title{
Enzyme linked immunosorbent assay for detecting antibody to Trichomonas vaginalis: Use of whole cells and aqueous extract as antigen
}

\author{
JOHN F ALDERETE \\ From the Department of Microbiology, University of Texas Health Science Center at San Antonio, \\ San Antonio, Texas, USA
}

SUMMARY An enzyme linked immunosorbent assay (ELISA) for detecting antibody to antigenic Trichomonas vaginalis macromolecules has been identified using whole cells or an aqueous protein extract as antigen. The test was developed under optimum conditions using serum samples from experimental animals. The sensitivity of the ELISA was equal to or greater than that obtained by radioimmunoprecipitation and electrophoresis-fluorography techniques. The ELISA was capable of assessing antibody responses during the development of lesions in animals inoculated subcutaneously and it reproducibly measured the individual classes immunoglobulins directed at $T$ vaginalis. The colorimetric assay was also suitable for showing cross reactivity between trichomonal species as well as between different strains of $T$ vaginalis. Conditions established for monitoring antibody to trichomanads in immunised rabbits or infected mice were equally effective for human materials, such as serum or vaginal washes. Serum from experimental animals or infected people showed high concentrations of IgG, IgA, and IgM antibody to trichomonads. Only antibodies of the IgG and IgA class were detected in vaginal washes from women with acute trichomoniasis. No IgE antibody to trichomonads was found under a variety of conditions in serum samples from patients or experimental animals.

\section{Introduction}

Although it probably entails cellular and humoral responses, the immunological response of the vaginal mucosa to Trichomonas vaginalis is poorly understood. Various approaches have been used to assess immunological responses of patients with urogenital trichomoniasis. ${ }^{1-10}$ An enzyme linked immunosorbent assay (ELISA) has been developed, which uses whole organisms as antigen and identifies immunoglobulins to $T$ vaginalis in body fluids. ${ }^{9}$ Sensitive radioimmunoprecipitation and electrophoresis fluorography tests have also shown serum IgG antibodies against highly immunogenic trichomonal glycoproteins. ${ }^{11}$ Furthermore, serum from experimental animals ${ }^{11}{ }^{12}$ and man (Alderete, Spence, and Suprun, unpublished observation) had antibodies to membrane proteins of a trichomonad that is pathogenic to man. ${ }^{12}$ These data ${ }^{1-12}$ help to

Address for reprints: $\mathrm{Dr}$ John $\mathrm{F}$ Alderete, Department of Microbiology, The University of Texas Health Science Center at San Antonio, 7703 Floyd Curl Drive, San Antonio, Texas 78284, USA

Accepted for publication 11 November 1983 define the antibody response of the host to infestation by this organism.

To continue the immunological analysis of the various strains of pathogenic $T$ vaginalis and identify similar and distinct immunogens of individual fresh isolates or long term grown trichomonads, ${ }^{10}{ }^{11}$ it was important to improve the conditions for using a sensitive ELISA to measure antibody concentrations in various fluids. In this report I show the application and merit of an ELISA for detecting antibody in serum samples or vaginal washes and for identifying immunoglobulin classes and crossreactivity between trichomonal strains and species. I describe optimum conditions using whole cells and a defined aqueous protein preparation of $T$ vaginalis as antigen.

\section{Materials and methods}

TRICHOMONAS VAGINALIS AND OTHER TRICHOMONAL ORGANISMS

All trichomonal organisms were grown in vitro as previously described. ${ }^{11-13}$ Only organisms grown for less than one month after receipt were used for all experiments. $T$ vaginalis strains NYH286, NYH272, 
IR78, and ATCC30001 and Tritrichomonas foetus KV-1 were provided by Dr Miklós Müller of Rockefeller University. All others were purchased from the American Type Culture Collection (ATCC, Rockville, Maryland, USA). All trichomonads except Trichomonas tenax produced lesions (fig 1a) after subcutaneous inoculation of $5 \times 10^{6}-10 \times 10^{6}$ organisms into the hind quarters of 4-6 week old female BALB/c mice. ${ }^{11} 14$ Tt foetus KV-1 routinely produced an open abscess (fig $1 \mathrm{~b}$ ) rather than the standard nodule formation that is used by others as a measure of pathogenicity. ${ }^{14} T$ vaginalis strain JH31A, which is generally considered to be less pathogenic, yielded lesions of equal size and severity to those produced by other $T$ vaginalis strains tested in our laboratory (fig 1a) using these inoculum sizes. ${ }^{11} 14$

\section{ATTACHMENT OF ANTIGEN TO POLYVINYLCHLORIDE (PVC) MICROTITRE PLATES}

Trichomonads at the logarithmic phase of growth ${ }^{15}$ representing densities of no greater than $1 \times 10^{6}$ motile organisms $/ \mathrm{ml}$ were washed at least three times in phosphate buffered saline (PBS). ${ }^{15}$ The organisms were resuspended to a density that would yield the desired numbers of cells in individual wells of 96 well PVC microtitre plates (Dynatech Laboratories, Alexandria, Virginia, USA) using $50 \mu \mathrm{l}$ of suspension (fig 2). The suspension was dried in air at $37^{\circ} \mathrm{C} .{ }^{16} \mathrm{~A}$ $50 \mu \mathrm{l}$ volume of $95 \%$ ethanol was added to each well

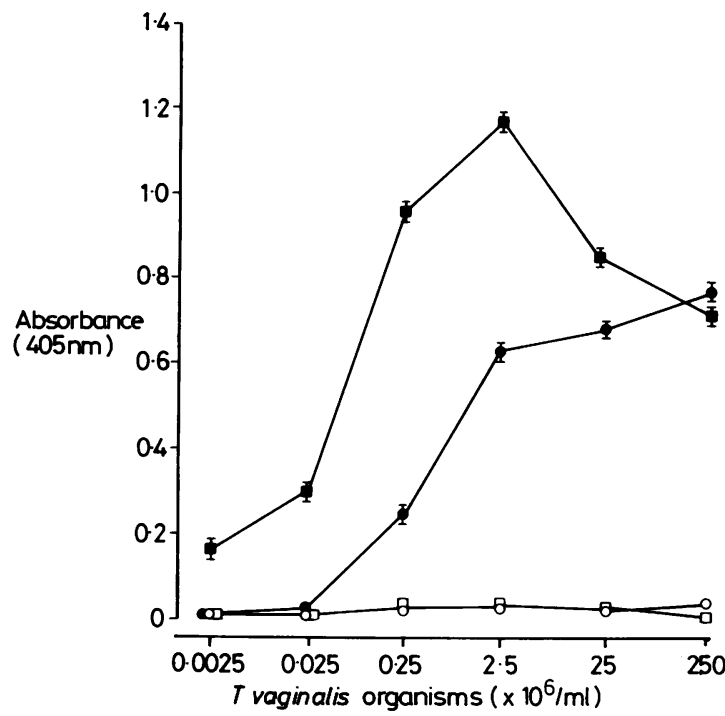

FIG 2 Comparative sensitivity of ELISA at different concentrations of $T$ vaginalis strain 286. All serum samples were diluted $1 / 100$ with PBS and bovine serum albumin, and standard deviations were $<0.02$ for all control values. $(O=$ normal mouse serum; $\square=$ normal rabbit serum; $\bullet=$ mouse anti-286 (day 21$) ; \square=$ rabbit anti-286 (day 42).

and the plates were again dried at $37^{\circ} \mathrm{C}$ and stored at $4^{\circ} \mathrm{C}$ until used. ${ }^{16}{ }^{17}$ The antigen remained stable for several months. Wells were also coated with

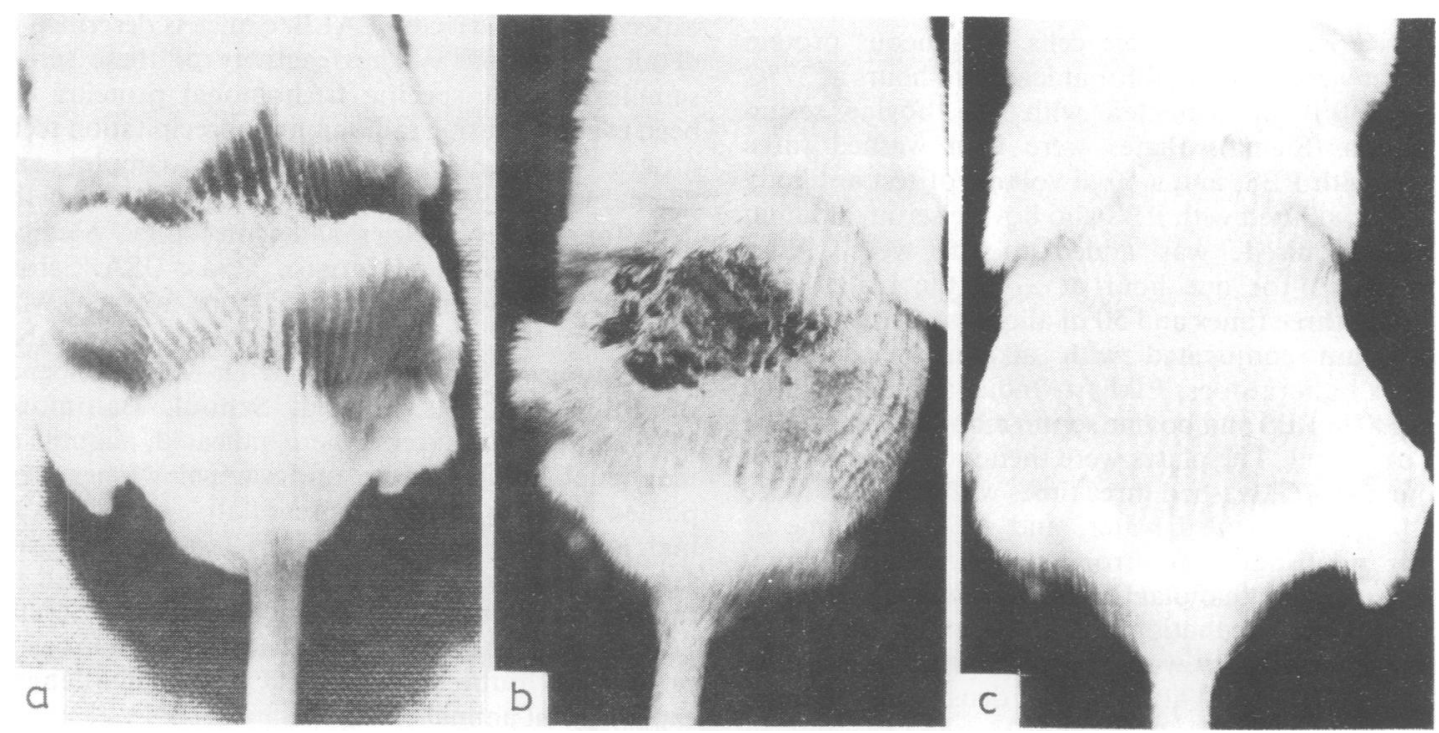

FIG 1 Lesion and abscess formation in mice six to ten days after subcutaneous inoculation with: a) human $T$ vaginalis strain 286, and b) $T t$ foetus $K V-1$, the pathogenic bovine trichomonad, c) no lesion after inoculation with medium control, culture filtrate, or T tenax. 
organisms suspended in carbonate buffer, ${ }^{918}$ but these trichomonads were less viable and gave variable ELISA results with high standard deviations compared with those from trichomonads fixed in ethanol.

An aqueous protein extract of $T$ vaginalis was prepared using a French pressure cell. At least $10 \mathrm{ml}$ $\left(1.25 \times 10^{9}\right.$ to $2.50 \times 10^{9}$ organisms) of $T$ vaginalis in PBS containing $0.001 \mathrm{~mol} / 1$ phenylmethylsulphonylfluoride (Sigma Chemical, St Louis, Missouri, USA) were subjected to $689 \cdot 5$ bar (10 000 $\mathrm{lbf} / \mathrm{in}^{2}$ pressure in a standard French pressure cell (American Instrument, Silver Spring, Maryland, USA). Recovered material was clarified by sequential centrifuging at $600 \times g$ for 15 minutes and $48000 \times g$ for 30 minutes at $4^{\circ} \mathrm{C}$. Further centrifuging at $100000 \times g$ did not result in pelleting of additional material. The composition of this aqueous soluble extract has recently been examined using radioimmunoprecipitation and electrophoretic techniques with parasites labelled intrinsically and extrinsically (Alderete and Garza, unpublished observation). Antigens identical to those found on membranes of intact $T$ vaginalis organisms were present in this aqueous protein extract. ${ }^{12}$ Protein concentrations were measured by the method of Bradford, ${ }^{19}$ and the extract was diluted in carbonate buffer ${ }^{18}$ so that a $50 \mu$ l volume representing different amounts of protein (fig 3) was aliquoted into PVC microtitre plate wells.

\section{ENZYME LINKED IMMUNOSORBENT ASSAY \\ (ELISA)}

Wells coated with whole cells or aqueous protein extract were pretreated for at least two hours at $37^{\circ} \mathrm{C}$ with PBS supplemented with $1 \%$ bovine serum albumin (Sigma). Plates were then washed three times with PBS, and a $50 \mu$ l volume of test antibody reagent, diluted with PBS and bovine serum albumin when required, was added to the wells. After incubation for one hour at $37^{\circ} \mathrm{C}$ the plates were washed three times and $50 \mu \mathrm{l}$ aliquots of appropriate antiserum conjugated with alkaline phosphatase (Miles Laboratories, Elkhart, Indiana, USA) diluted $1 / 1000$ in PBS and bovine serum albumin were added to each well. The plates were then incubated for one hour at $37^{\circ} \mathrm{C}$, washed three times with PBS and twice with sterile distilled water, and a $50 \mu \mathrm{l}$ volume of $1 \mathrm{mg} / \mathrm{ml}$ disodium p-nitrophenyl phosphate (Sigma) prepared in diethanolamine buffer ${ }^{18}$ was added to the wells. After incubation for $30-60$ minutes at $37^{\circ} \mathrm{C}$ antibody reactivity was recorded using a MicroElisa Reader (Dynatech) at an optical density of $405 \mathrm{~nm}$.

\section{SERUM SAMPLES}

The production of control serum and antiserum against $T$ vaginalis strains, $T t$ foetus $\mathrm{KV}-1$, and $T$

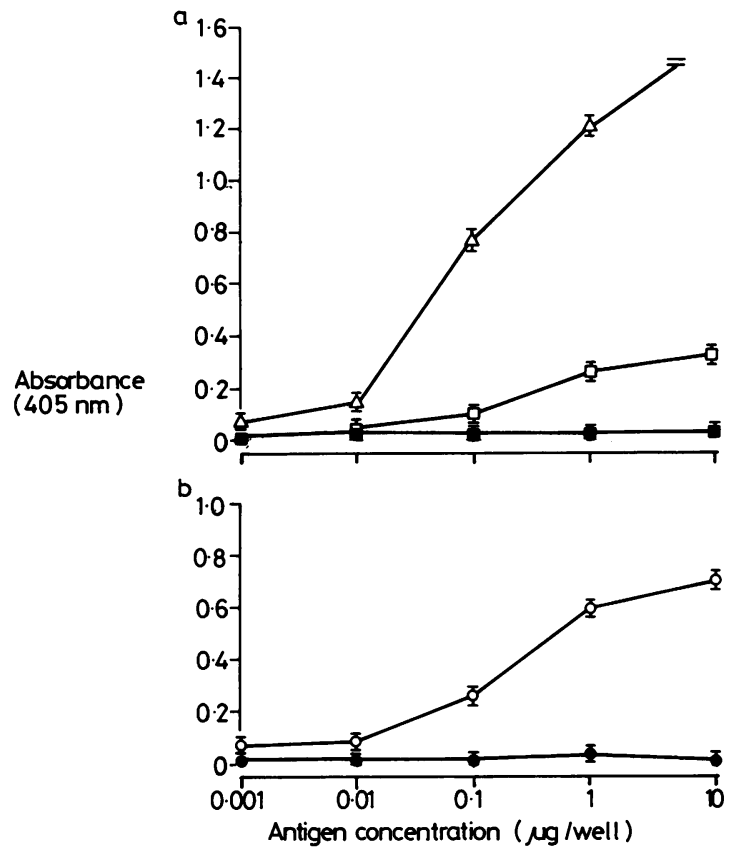

FIG 3 ELISA reactivity using aqueous protein extract at different concentrations. $\square=$ normal rabbit serum (1/100 dilution); $\Delta=$ rabbit anti-286 (1/100 dilution); $\square=$ rabbit anti-286 (1/1000 dilution); $\bullet=$ normal mouse serum (1/100 dilution); $\bigcirc=$ mouse anti-286 (1/100 dilution.

tenax in immunised New Zealand white rabbits or experimentally infected BALB/c mice is described in detail elsewhere. ${ }^{11} 12$ The reactivity of these serum samples against specific trichomonal proteins has been evaluated using radioimmunoprecipitation techniques. ${ }^{1112}$ Control human serum samples and vaginal washes were provided by Dr $R$ Gibbs of the department of obstetrics and gynecology, Medical Center Hospital, San Antonio, Texas, USA. Serum samples and vaginal washes from women with symptomatic and microscopically detectable trichomoniasis were provided by Dr Michael Spence of Johns Hopkins Medical School, Baltimore, Maryland, USA. Except where indicated, aliquots of individual human serum and vaginal washes were pooled in order to have representative samples with high antitrichomonal reactivity. These human serum samples and washes have recently been analysed by radioimmunoprecipitation techniques (Alderete, Suprun, and Spence, unpublished observation) as in previously published reports using challenged experimental animals. ${ }^{11} 12$

A volume of $5 \mathrm{ml}$ of a vaginal wash obtained using sterile PBS was centrifuged at $17500 \times g$ to remove any insoluble debris. The clarified supernatant was 
then dialysed against distilled water and concentrated tenfold by ultrafiltration using an Amicon membrane filter with a molecular weight cutoff of 10000 (PM 10; Amicon, Lexington, Massachusetts, USA). The processed vaginal wash solution was either used immediately or diluted in PBS and bovine serum albumin as described and frozen at $-70^{\circ} \mathrm{C}$ until used.

\section{Results}

ANTIGEN TITRATION USING WHOLE CELLS OR AQUEOUS PROTEIN EXTRACT

To find the optimum conditions for the ELISA using either intact $T$ vaginalis strain 286 or an aqueous extract derived from strain 286 as antigen, PVC microtitre wells were prepared using various concentrations as shown in figs 2 and 3 . At $1 / 100$ dilutions serum from immunised rabbits or experimentally infected mice ${ }^{11}$ showed maximum reactivity when wells were coated with $50 \mu \mathrm{l}$ antigen containing $1.25 \times 10^{5}$ whole cells $\left(2.5 \times 10^{6} / \mathrm{ml}\right)($ fig 2$)$. Similarly, as little as $0.1 \mu \mathrm{g}$ protein was detected after coating the wells with an aqueous extract (fig 3) known to contain trichomonal membrane proteins (Alderete and Garza, unpublished observation). ${ }^{12}$ Under similar conditions control serum samples produced minimum background levels whatever numbers of parasites or concentrations of protein were used. Under our experimental conditions, the use of carbonate buffer to attach whole cells to PVC plates or the use of an aqueous extract generated by high pressure yielded highly variable results and diminished reactivity (data not shown).

ANTIBODY RESPONSES IN CHALLENGED MICE Mice have been used to evaluate the pathogenic capabilities of $T$ vaginalis (fig 1). ${ }^{10} 14$ IgG to trichomonal protein antigens has been assessed in serum from control and infected mice. ${ }^{11} 12$ It was therefore interesting to examine the changes in response of all the immunoglobulins, and table I shows that serum possessed high concentrations of antibody against either whole cell or aqueous protein antigen at different times after infection. Only ELISA endpoints $20 \%$ greater than the absorbance for normal mouse serum were considered positive, and all test serum samples were reactive at $1 / 10000$ except for those taken on days 7 and 30 and tested with the aqueous extract.

Figure 4 shows representative data from one experiment containing quadruplicate samples of immuno-

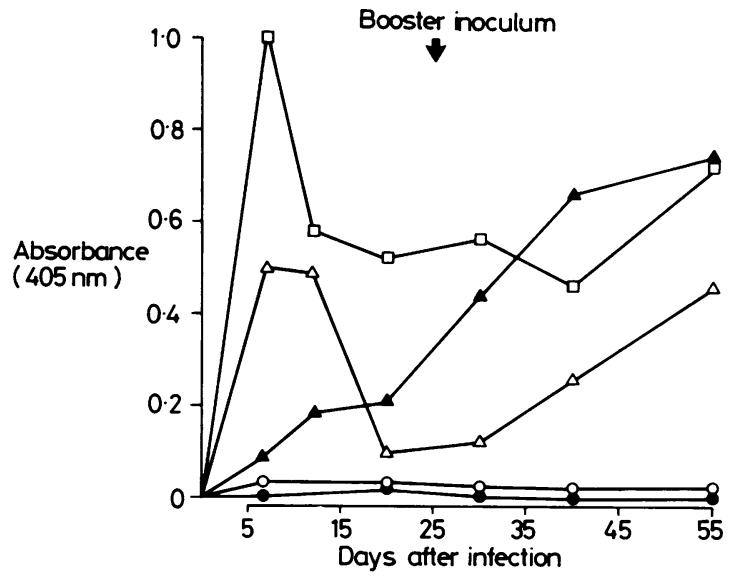

FIG 4 Representative course of responses of different immunoglobulin types in pooled serum samples of mice infected with $T$ vaginalis strain 286 as detected by antimouse second antibodies and using strain 286 as antigen in a whole cell ELISA. Immunoglobulin types in normal mouse serum reactive against $T$ vaginalis gave results as shown for normal mouse serum control.

Normal mouse serum and antiserum against strain 286 were diluted $1 / 100$, and standard deviations were $<0.02$ for all values shown. $1 \bigcirc=$ normal mouse serum; - = anti-IgE; $\square=$ anti-IgM; $\mathbf{\Delta}=$ anti-IgG; $\triangle=$ anti-IgA.)

TABLE I Antibody absorbance in serum from infected mice shown by ELISA using whole T vaginalis strain 286 cells or an aqueous protein extract as antigen

Mean (SD)† absorbance $(405 \mathrm{~nm})$ at:

\begin{tabular}{|c|c|c|c|c|c|}
\hline & & & & & \\
\hline Antigen & Dilution of serum* & Day 7 & Day 14 & Day 30 & Day 50 \\
\hline $\begin{array}{l}\text { Whole cells } \\
\left(1 \cdot 25 \times 10^{6} / \text { well }\right)\end{array}$ & $\begin{array}{l}1 / 10 \\
1 / 100 \\
1 / 1000 \\
1 / 10000\end{array}$ & $\begin{array}{l}0.201(0.004) \\
0.234(0.020) \\
0.190(0.007) \\
0.025(0.015)\end{array}$ & $\begin{array}{l}0.394(0.010) \\
0.409(0.013) \\
0.152(0.052) \\
0.047(0.015)\end{array}$ & $\begin{array}{l}0.481(0.040) \\
0.574(0.076) \\
0.301(0.015) \\
0.085(0.010)\end{array}$ & $\begin{array}{l}0.557(0.017) \\
0.726(0.022) \\
0.594(0.011) \\
0.122(0.008)\end{array}$ \\
\hline $\begin{array}{l}\text { Aqueous protein extract } \\
(0 \cdot 1 \mu \mathrm{g} / \text { well })\end{array}$ & $\begin{array}{l}1 / 10 \\
1 / 100 \\
1 / 1000 \\
1 / 10000\end{array}$ & $\begin{array}{l}0.155(0.013) \\
0.069(0.006) \\
0.019(0.011) \\
0.014(0.005)\end{array}$ & $\begin{array}{l}0.381(0.003) \\
0.176(0.005) \\
0.087(0.015) \\
0.109(0.011)\end{array}$ & $\begin{array}{l}0.314(0.011) \\
0.119(0.009) \\
0.045(0.003) \\
0.016(0.004)\end{array}$ & $\begin{array}{l}0.709(0.054) \\
0.404(0.058) \\
0.285(0.012) \\
0.080(0.012)\end{array}$ \\
\hline
\end{tabular}

*Serum was diluted with phosphate buffered saline. Normal mouse serum diluted $1 / 10$ gave absorbances of $<0 \cdot 015$ with either antigen. tOf triplicate samples from three different experiments. 
globulin classes in pooled serum samples reactive to $T$ vaginalis from infected mice. Serum IgM, IgA, and IgG were each detected, and the concentrations of these antibodies increased as the lesions developed. Maximum IgA and IgG concentrations parallelled the resolution of lesions, which occurred about 14 days after inoculation (fig 1a). Mice appeared normal, and nodules were resolving by day 20 . No IgE was seen in infected mice throughout the experiment. Booster injection resulted in dramatic rises in total antitrichomonal IgG antibody concentrations and produced another increase in serum IgA concentrations. These data define the changes in the immunoglobulin classes of antibody as the lesions develop and regress in mice.

\section{CROSSREACTIVITY AMONG TRICHOMONADS}

I also examined the similarity between different pathogenic strains with the ELISA, using $T$ vaginalis strain 286 as the test antigen (fig 5). The serum of rabbits immunised individually with four different

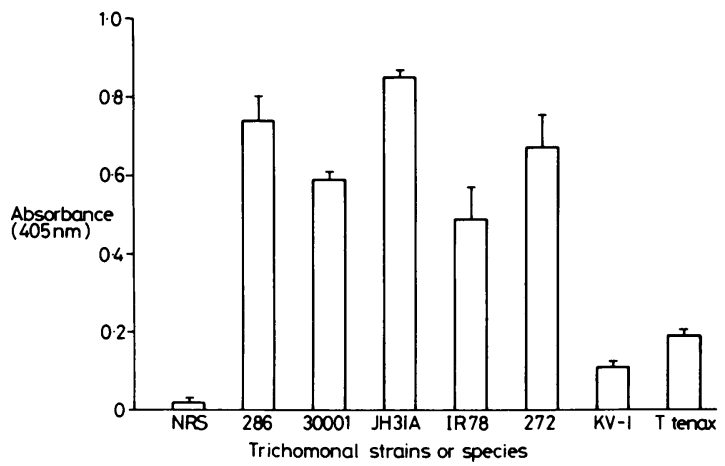

FIG 5 Detection of antigens in $T$ vaginalis strain 286 by ELISA using whole cell antigen with antiserum produced in rabbits individually immunised with homologous strain 286, heterologous $T$ vaginalis strains $30001, J H 31 A$, IR78, and 272, Tt foetus $K V-1$ (a pathogenic bovine trichomonad), or $T$ tenax (a non-pathogenic trichomonad), (NRS = normal rabbit serum.) human trichomonads contained IgG. $T$ tenax, a member of the normal flora of the oral cavity, and $T t$ foetus KV-1, a bovine trichomonad, showed marginal crossreactivity compared with normal rabbit serum. These results confirm recently published reports, which identified the various antisera and antigens common to these trichomonads, in which serum from $T$ tenax and $T t$ foetus immunoprecipitated a small number of radiolabelled $T$ vaginalis polypeptides. ${ }^{11} 12$

\section{HUMAN TEST SAMPLES AND ELISA}

Tables II and III show the application of the ELISA using whole cell antigen under the established optimum conditions (fig 2) for analysing antitrichomonal antibody in human body fluids. Strain 286 was used because it had already been immunologically analysed ${ }^{11} 12$ and because it was recognised by antisera to all heterologous strains of $T$ vaginalis (fig 4). Interestingly, all control human serum samples tested produced high background concentrations for each antibody class except IgE. Combined serum samples from patients with trichomonal vaginitis had higher concentrations of all antibody classes except IgM than controls at dilutions of $1 / 10$ and $1 / 100$. As with infections in mice (fig 4) IgE antibody to $T$ vaginalis was not found under these conditions. Similarly, a concentrated preparation of

TABLE III Detection of antibody in pooled vaginal washes from 3-6 infected patients* by ELISA.

\begin{tabular}{lll}
\hline & \multicolumn{2}{l}{ Mean (SD)+ absorbance $(405 \mathrm{~nm})$} \\
\cline { 2 - 3 } Vaginal wash & Undiluted & Diluted $1 / 10$ \\
\hline Infected woman 1 & $1.308(0.020)$ & $0.095(0.012)$ \\
Infected woman 2 & $0.799(0.050)$ & $0.074(0.021)$ \\
Infected woman 3 & $1.115(0.084)$ & $0.472(0.068)$ \\
\hline
\end{tabular}

*Infection confirmed on microscopy.

+Of triplicate samples from three separate experiments. Vaginal washes from uninfected women gave absorbances of about 0.065 $(0 \cdot 015)$ at the same dilutions.

TABLE II Representative antibody to $T$ vaginalis in pooled serum samples or vaginal washes from 3-6 infected patients* on ELISA using whole $T$ vaginalis strain 286 cells as antigen

\begin{tabular}{|c|c|c|c|c|c|}
\hline \multirow[b]{2}{*}{ Body fluid } & \multirow[b]{2}{*}{ Dilutiont } & \multicolumn{4}{|c|}{ Mean (SD) $\ddagger$ absorbance $(405 \mathrm{~nm})$ of: } \\
\hline & & IgG antibody & $\operatorname{Ig} A$ antibody & IgM antibody & IgE antibody \\
\hline \multicolumn{6}{|l|}{ Serum from: } \\
\hline Healthy subject & $1 / 10$ & $0.256(0.052)$ & $0.030(0.025)$ & $0 \cdot 281(0 \cdot 022)$ & Nil \\
\hline Infected patient & $1 / 10$ & $0.885(0.010)$ & $0.792(0 \cdot 021)$ & $0.475(0.010)$ & $0.003(0.002)$ \\
\hline Infected patient & $1 / 100$ & $0.921(0.015)$ & $0.342(0.005)$ & $0.099(0.020)$ & Nil \\
\hline \multicolumn{6}{|l|}{ Vaginal wash from: } \\
\hline Healthy subject & $1 / 2$ & $0.035(0.031)$ & $0.037(0.005)$ & $0.033(0.011)$ & Nil \\
\hline Infected patient & $1 / 2$ & $0.229(0.022)$ & $0.238(0.059)$ & $0.019(0.019)$ & Nil \\
\hline
\end{tabular}

*Infection confirmed on microscopy. †Dilution of body fluid with phosphate buffered saline.

$\neq$ Of triplicate samples from three different experiments. 
pooled vaginal washes had IgG and IgA antibody but no identifiable IgM or IgE. These results agreed with those obtained from six separate washes. Finally, titration of individual vaginal washes of selected patients showed that concentrations of antibody were measurable only, at dilutions of $1 / 10$ or $1 / 100$.

\section{Discussion}

In this study we established optimum conditions to enable the highly sensitive and reproducible ELISA to detect antibody to pathogenic $T$ vaginalis (figs 2 and 3). This report extends the work of others who, in a similar assay, ${ }^{9}$ have shown the reactivity of human serum and vaginal washes with trichomonads. Sensitivity of the microassay was confirmed by: a) the detection of antibody in serum from experimental animals at dilutions of $1 / 1000$ or $1 / 10000$ (table 1); b) the recognition of as little as $50 \mathrm{ng}$ protein in an antigen extract containing a large number of trichomonal antigens (fig 3); c) the ability to identify the type of immunoglobulin present in serum from experimental animals (fig 4) and man (Table II) as well as in vaginal wash material from infected women (tables II and III); and d) the ability to measure antigenic similarities among trichomonal species (fig 5).

Earlier immunological analysis with radioimmunoprecipitation techniques ${ }^{1112}$ and preliminary studies with whole cells as test antigen in an ELISA showed that many serum samples generated against different strains of pathogenic trichomonads recognised $T$ vaginalis strain 286 . I thus avoided using antigenically different organisms to standardise the ELISA. All pooled serum samples from mice infected with fresh isolates and serum samples from patients with microscopically confirmed trichomoniasis also gave high antibody reactivity using strain 286 in the ELISA.

We found high concentrations of IgM and IgA in serum from infected mice that reacted with trichomonal antigens (fig 4). The use of specific anti-IgM or anti-IgA second antibody in radioimmunoprecipitation studies ${ }^{11} 12$ did not identify any new radiolabelled antigen after electrophoresis-fluorography. Thus, either IgA, IgM, and IgG recognise similar protein antigens, or the $\operatorname{IgA}$ and $\operatorname{IgM}$ are against trichomonal immunogens not radiolabelled by procedures used in previous studies. ${ }^{11} 12$ The immunoprophylactic nature of IgA and other immunoglobulins in serum or mucosal surfaces against $T$ vaginalis in animals and infected women (tables I and III) remains undefined.

The absence of IgE in serum from subcutaneously challenged mice (fig 4) and serum and vaginal washes from patients with urogenital trichomoniasis (table II) is also noteworthy. Similarly, IgE reactivity against an aqueous protein extract (data not shown) was not detected. The low frequency of specific IgE antibody to $T$ vaginalis in $\operatorname{man}^{18}$ may reflect a response by selected hosts to unique manifestations of trichomoniasis or may result from the non-specific binding of some immunoglobulins to parasite surfaces. ${ }^{20}$ It appears, however, that the recent report of IgE antibody being elicited by trichomonal products using various immunisation regimens ${ }^{21}$ shows that humoral responses in the host during natural infections require further clarification.

The detection of antibody by ELISA using whole cell antigen in serum from people with no history of urogenital trichomoniasis is noteworthy (table II). These highly reactive serum samples, however, failed to immunoprecipitate any radiolabelled trichomonal protein (Alderete, Suprun, and Spence, unpublished observation). ${ }^{11} 12$ These observations may be consistent with earlier reports from this laboratory on the acquisition of specific plasma proteins by specialised receptors on membranes of intact $T$ vaginalis organisms. ${ }^{15} 20$ It appears, therefore, that some natural reactivity among healthy subjects is not necessarily directed at specific trichomonal proteins. Alternatively, immunological priming toward nonproteinaceous antigens by non-pathogenic trichomonads such as $T$ tenax, a member of the normal flora of the oral cavity, might be responsible for the results seen. Interestingly, the absence of systemic infections by $T$ vaginalis may correlate with these observations. The data indicate that further studies of $T$ vaginalis are necessary to define the precise antigens for the future use of purified components in an ELISA, as has been shown for other microbial models. ${ }^{16}$ Selected parasite molecules may be more accurate in examining serum from and diagnosing infection in patients.

The immunological variables in trichomonal vaginitis are complex and poorly defined. Knowledge of immune responses of hosts to trichomonads will lead to an understanding of any immunopathological mechanisms related intimately or remotely to infection, and will help us develop effective immunoprophylactic measures against $T$ vaginalis infection of the vaginal mucosa in man. This disease is complicated by the considerable heterogeneity of serotypes $^{10}$ and the absence of a sensitive and specific quantitative assay. The usefulness of ELISA for measuring antibody to bacterial, viral, and cellular antigens has been well documented. ${ }^{16}{ }^{17}{ }^{22-24}$ Development of this microassay may help to define further the antigenic properties of pathogenic $T$ vaginalis and provide a way of detecting antibody in aqueous solutions. 
This work was supported by Public Health Service grant AI 19142 from the National Institutes of Health to JFA. I thank Devvie Plummer for advice; G E Garza, L Oli Suprun, and M McLemore for technical assistance; and Diane Henley and Mary Devadoss for secretarial help.

\section{References}

1. Green RL, Scales RW, Kraus SJ. Increased serum immunoglobulin E concentrations in venereal disease. Br J Vener Dis 1976;52:257-60.

2. Kramar J, Kucera K. Immunofluorescence demonstration of antibodies in urogenital trichomoniasis. J Hyg Epidemiol Microbiol Immunol (Praha) 1966; 10: 85-8.

3. Teras J, Nigesen U, Jaakmees H, Roigas E, Tompel, H. The agglutionogenic properties of Trichomonas vaginalis in human organism. Wiad Parazytol 1966; 12:370-7.

4. Jaakmees H, Teras J, Roigas E, Nigesen U, Tompel $H$. Complement-fixing antibodies in the blood sera of men infested with Trichomonas vaginalis. Wiad Parazytol 1966;12: 378-84.

5. McEntegart MG. The application of a haemagglutination technique to the study of Trichomonas vaginalis infections. $J$ Clin Pathol 1952;5:275-80.

6. Ackers JP, Lumsden WHR, Catterall RD, Coyle R. Antitrichomonal antibody in the vaginal secretions of women infected with $T$ vaginalis. Br J Vener Dis 1975;51:319-23.

7. Mathews HM, Healy GR. Evaluation of two serological tests for Trichomonas vaginalis infection. J Clin Microbiol 1983; 17: 840-3.

8. Su KE. Antibody to Trichomonas vaginalis in human cervicovaginal secretions. Infect Immun 1982; 37: 852-7.

9. Street DA, Taylor-Robinson D, Ackers JP, Hanna NF, McMillan A. Evaluation of an enzyme-linked immunosorbent assay for the detection of antibody to Trichomonas vaginalis in sera and vaginal secretions. Br J Vener Dis 1982;58:330-3.

10. Honigberg BM. Trichomonads of importance in human medicine. In: Krier JP, ed. Parasitic protozoa. Vol 2. London: Academic Press, 1978; 275-454.
11. Alderete JF. Antigen analysis of several pathogenic strains of Trichomonas vaginalis. Infect Immun 1983;39:1041-7.

12. Alderete JF. Identification of immunogenic and antibodybinding membrane proteins of pathogenic Trichomonas vaginalis. Infect Immun 1983; 40: 284-91.

13. Alderete JF, Pearlman E. Pathogenic Trichomonas vaginalis cytotoxicity to cell culture monolayers. Br J Vener Dis 1984; 60:99-105.

14. Honigberg BM, Livingston MC, Frost JK. Pathogenicity of fresh isolates of Trichomonas vaginalis: "the mouse assay" versus clinical and pathologic findings. Acta Cytol (Baltimore) 1966; 10:353-61.

15. Peterson KM, Alderete JF. Host plasma proteins on the surface of pathogenic Trichomonas vaginalis. Infect Immun 1982;37:755-62.

16. Morrison-Plummer J, Alderete JF, Baseman JB. Enzymelinked immunosorbent assay for the detection of serum antibody to outer membrane proteins of Treponema pallidum. BrJ Vener Dis 1983;59:75-9.

17. Feltzer PM, Pepose JS, Bishop NH, Miller JN. Microassay for immunoglobulin $G$ antibodies to Treponema pallidum with radioiodinated protein A from Staphylococcus aureus. immunoglobulin $G$ response in experimental syphilis in rabbits. Infect Immun 1978;21: 163-70.

18. Voller A, Bidwell D, Bartlett A. Microplate enzyme immunoassays for the immunodiagnosis of virus infections In: Rose NR, Friedman H, eds. Manual of clinical immunology Washington DC: American Society for Microbiology, 1976; 506-12.

19. Bradford MM. A rapid and sensitive method for the quantitation of microgram quantities of protein utilizing the principle of protein-dye binding. Anal Biochem 1976;72:248-54.

20. Peterson KM, Alderete JF. Acquisition of $\alpha_{1}$-antitrypsin by a pathogenic strain of Trichomonas vaginalis. Infect Immun 1983;40:640-6.

21. Yano A, Aosai F, Yui K, Kojima S, Kawana T. Genetic regulation of IgE antibody response to Trichomonas vaginalis in mice and human, and partial characterization of Trichomonas vaginalis antigen. Mol Biochem Parasitol 1982; Supplement: 50.

22. Cobbald SP, Waldmann $\mathbf{H}$. A rapid solid-phase enzyme-linked binding assay for screening monoclonal antibodies to cell surface antigens. J Immunol Methods 1981;44:125-33.

23. Horowitz SA, Cassell GH. Detection of antibodies to Mycoplasma pulmonis by an enzyme-linked immunosorbent assay. Infect Immun 1978; 22: 161-70.

24. Anthony RL, Christensen HA, Johnson CM. Micro-enzymelinked immunosorbent assay (ELISA) For the serodiagnosis of New World leishmaniasis. Am J Trop Med Hyg 1980;29: 190-4. 